University of Michigan Law School

University of Michigan Law School Scholarship Repository

Articles

Faculty Scholarship

1910

\title{
Attachments on Unliquidated Demands
}

John R. Rood

University of Michigan Law School

Available at: https://repository.law.umich.edu/articles/1324

Follow this and additional works at: https://repository.law.umich.edu/articles

Part of the Legal Remedies Commons

\section{Recommended Citation}

Rood, John R. (1904-1918). "Attachments on Unliquidated Demands." Mich. L. Rev. 8 (1910): 323-5.

This Response or Comment is brought to you for free and open access by the Faculty Scholarship at University of Michigan Law School Scholarship Repository. It has been accepted for inclusion in Articles by an authorized administrator of University of Michigan Law School Scholarship Repository. For more information, please contact mlaw.repository@umich.edu. 
ATrachments on UnLiquidated Denands.-If the creditor should not have the aid of attachment to recover on unliquidated demands, why not? It is true that attachment as a security for the satisfaction of the judgment that may be recovered in an action pending or just commenced was unknown to the general common law of England, and existed only in a restricted form as a special custom of London and other places in the form of garnishment till it was introduced into the New England colonies by an early statute of Massachusetts, whence its utility commended it so that it was soon adopted in all the colonies. Therefore, it may be said that if there is no authority for attachment on unliquidated demands under the statute there is no authority at all-that the proceeding is purely statutory, and authority must be found in the statute for each case.

But this argument does not apply to the point now under discussion under any of the statutes so far as we are aware; for whether the statute permits attachment "in any action on contract," or "in any action for the recovery of money only," or "in any action for the recovery of damages," which are some of the most common statutory forms of expression, actions for unliquidated damages are as much included within the terms of the statutes as actions on liquidated demands. This argument, when applied to this class of cases works to the opposite conclusion. The argument when applied to this class of cases would be, that it is for the legislature to say what cases they will extend the new remedy, and it is not for the court to deny it if the legislature has given it, though inconvenience may follow. The fact is that this old stock argument against attachments and garnishments in all debatable cases never was much heard on this class of cases. Why then has not 
the remedy been allowed on unliquidated demands generally? Should we not rather say, remedial statutes should be so construed as to advance the remedy?

The rule that attachment does not lie in aid of suits on unliquidated demands was first declared in the case of Fisher v. Consequa, 2 Wash. C. C. 382 , Fed. Cas. No. 4816 , by Justice WAsHingron in the circuit court of the United States for the district of Pennsylvania, in I809; and was occasioned by the fact that the statute under which the attachment issued in that case allowed the remedy only to-recover a debt; and in disposing of the question Justice WASHINGTON said: "It must be admitted, that, according to a strict and literal construtcion of the act of assembly, the foreign attachment is confined to cases of debt. $* * *$ What is a debt? In strict law language, it is a precise sum due by express agreement, and does not depend upon any after calculation to ascertain it. The remedy for recovery of it is by action of debt, and frequently by action of indebitatus assumpsit. But is this the only case within the mischief intended to be remedied by the law? $* * *$ The uncertainty of the sum due, does not, in the common understanding of mankind, render it less a debt. A promise, whether express or implied, to pay as much as certain goods or labor are worth, or as much as the same kind of goods may sell for on a certain day, or at a certain market; or to pay the difference between the value of one kind of goods and another, creates, in common parlance, a debt; and the person entitled to performance does not speak of his claim as for damages, but for a debt, to the amount which he considers himself entitled to. But it is not every claim that, upon a fair construction of this law, or even in common parlance, can be denominated a debt. For, in the first place, the demand must arise out of a contract, without which no debt can be created; and the-measure of the damages must be such as the plaintiff can aver by affidavit to be due; without which, special bail (which the defendant, by giving, may dissolve the attachment) cannot regularly be demanded. It follows from this that a foreign attachment will not lie for demands which arise ex delicto, or where special bail cannot be required." And therefore it was held that the attachment was proper in that case, which was for delivering tea inferior to contract.

It will be observed that the court in this case gave a very liberal interpretation to the statute, and in fact stretched it to cover the case. Thus the law stood for ten years; when he case of Clark v. Wilson (1819), 3 Wash. C. C. 560 , Fed. Cas. No. 284I, came before the same court and judge, under the same statute; and in this case the court held that the statute could not be extended to sustain an attachment in an action for damages for refusal to employ plaintiff's ship on a voyage to Montevidio at $\$ 670$ per month or fraction thereof; and in referring to Fisher v. Consequa in that case, Justice WASHINGTON said: "The principle decided in that case was, that a demand arising ex contractu, the amount of which was ascertained, or which was susceptible of ascertainment by some standard referable to the contract itself, sufficiently certain to enable the pliantiff by affidavit to aver it, or a jury to find it; might be the foundation of a proceeding by way of foreign attachment, without reference to the form of action, or to the technical 
definition of debt, the expression used in the law. $* * *$ This then, is a case, in which unliquidated damages are demanded, in which the contract alleged as the cause of action affords no rule for ascertaining them, in which the amount is not, and cannot with propriety be, averred in the affdavit, and which is and must be altogether uncertain until the jury have ascertained it, for which operation no definite rule can be presented to them." This is the rule that has been declared since in the courts that have held attachment not to lie on unliquidated demands. Thus a rule laid down in giving a liberal construction to a narrow statute has been applied in giving a strict construction in the face of the express words of statutes which warranted no such limitation. The decisions on the question are very numerous, and in nearly or quite half of the states, a rule has been established as above stated without anything in the statute to warrant the limitation. In a few states it is squarely held that the fact that the demand sued on is not for liquidated damages is no objection to the attachment, since the judge can limit the amount to such sum as he deems reasonable.

In Michigan the rule laid down in the case of Clark v. Wilson was recognized but held not applicable, in the early case of Roelofson v. Hatch, 3 Mich. 277; and in the recent case of Showen v. J. L. Owens Co. (Oct. 4, 1909), - Mich. -, 122 N. W. 640, the court has again recognized the rule, and again held it inapplicable, sustaining an attachment in an action for damages for breach of warranty of machinery as sound and suitable for a purpose.

J. R. R. 